\title{
17. ROLE OF THE ERATOSTHENES SEAMOUNT IN COLLISIONAL PROCESSES IN THE EASTERN MEDITERRANEAN ${ }^{1}$
}

\author{
A.H.F. Robertson ${ }^{2}$ and Shipboard Scientific Party ${ }^{3}$
}

\begin{abstract}
The Eratosthenes Seamount plays a critical role in the tectonic evolution of the Eastern Mediterranean, including the uplift of the Troodos ophiolite of Cyprus. It also represents an important early collisional stage in the general process of plate suturing and mountain building. Drilling during Ocean Drilling Program Leg 160 has elucidated the history of the Eratosthenes Seamount from the late Mesozoic to the present day and has provided data to test several recent hypotheses concerning the tectonic evolution of the Eastern Mediterranean region. Specifically, it is inferred that the uplift of Cyprus at about 1.5 Ma was activated by collision of the seamount with the upper plate of a subduction zone on which Cyprus is located. During the late Mesozoic, the Eratosthenes Seamount underwent mainly deep-water pelagic deposition in a stable tectonic setting adjacent to the passive continental margin of North Africa. By the Miocene, the seamount was tectonically uplifted, perhaps in response to subduction or initial collision, and then underwent shallow-water carbonate deposition. At about the late Miocene to early Pliocene, the seamount underwent inferred extensional faulting and breakup, followed by rapid subsidence to water depths of up to $2000 \mathrm{~m}$. The data support the hypothesis that the Eratosthenes Seamount foundered as a consequence of collision with a convergent margin to the north. Regional uplift of Cyprus was, however, delayed until approximately $3 \mathrm{~m}$.y. later, possibly reflecting the time necessary for sufficient crustal thickening to take place at depth to trigger uplift. The tectonic processes outlined above are also applicable to the early stages of collision of a number of orogenic belts, including the Mediterranean Tethys and the Appalachians.
\end{abstract}

\section{INTRODUCTION}

A major objective of tectonic-related drilling during Ocean Drilling Program (ODP) Leg 160 in March-April 1995 was to test the hypothesis that the Eratosthenes Seamount is a crustal block in the process of breakup in response to subduction and incipient collision of the African and Eurasian plates in the Eastern Mediterranean (Fig. 1; Robertson, 1990; Woodside, 1991; Kempler, 1993). This collision could have been a driving force in uplift of the island of Cyprus, including the Troodos ophiolite. However, the tectonic setting and evolution of this critical segment of the plate boundary have remained poorly known, relative to the Mediterranean Ridge farther west (Cita and Camerlenghi, 1990; Fig. 1). Seismic data collected during sitesurvey work prior to Leg 160 (Limonov et al., 1994) were the basis for a hypothesis of a collisional process that could be tested by drilling a small number of relatively shallow holes $(<600 \mathrm{~m})$.

In this preliminary synthesis, we first summarize the shipboard information collected during the Eratosthenes Seamount-Cyprus transect. The lithology and age of the stratigraphic sequences in the four holes drilled are summarized in Figures 2 and 3. In the second part of this chapter, we utilize these data to test a collisional model for the Eratosthenes Seamount.

\section{LATE MESOZOIC TO EARLY TERTIARY}

The recorded history of the Eratosthenes Seamount began with the accumulation of shallow-water carbonates that are undated, but assumed to be of early Late Cretaceous age at Site 967 (Fig. 2). This unit is overlain by Upper Cretaceous deep-water carbonates that were poorly recovered and remain undated. Microfossil assemblages indi-

'Emeis, K.-C., Robertson, A.H.F., Richter, C., et al., 1996. Proc. ODP, Init. Repts, 160: College Station, TX (Ocean Drilling Program).

'Grant Institute of Geology, University of Edinburgh, West Mains Road, Edinburgh EH9 3JW, United Kingdom. a.robertson@ed.ac.uk

Shipboard Scientific Party is given in the list preceding the Table of Contents. cate that deep-water sedimentation persisted through Maastrichtian time, followed by a hiatus, until middle Eocene time. Similar pelagic carbonates, again of middle Eocene age, were recovered farther south at Site 966 . The sedimentary structures and the nature of the benthic foraminifers indicate a bathyal, relatively deep-water environment, with pelagic carbonate deposition in a regionally stable tectonic setting, free of input from sediment gravity flows (e.g., calciturbidites).

During Late Cretaceous to middle Eocene time, the Eratosthenes Seamount is assumed to have formed part of the passive margin of the North African plate to the south, perhaps as a marginal crustal fragment. The nature of the basement of the Eratosthenes Seamount is unknown, but it might represent transitional continental crust, intruded by mafic igneous rocks, in view of the strong magnetic anomaly beneath the seamount and adjacent seafloor area (Woodside, 1977). Farther north, within Tethys, regionally important tectonic events took place in the Late Cretaceous during the time interval recorded on the Eratosthenes Seamount, including the genesis and tectonic disruption of the Troodos and other ophiolites. No obvious evidence of these events is seen in the sedimentary record of the Eratosthenes Seamount, presumably because it then was well to the south of Tethyan areas that were experiencing active margin and collisional processes.

After the middle Eocene there was a hiatus, and the Eratosthenes Seamount was uplifted by at least $1 \mathrm{~km}$, followed by the deposition of shallow-water carbonates. Similar carbonates were deposited at the two most southerly sites (Sites 965 and 966). The limestones at Site 967 are provisionally dated as, in part, early Miocene, based on benthic foraminifers, referable to the Family Orbitoididae (I. Premoli Silva, pers. comm., 1995). It is hoped that post-cruise studies will indicate the time span recorded by the limestones at both sites. Taken with the evidence from downhole geophysical logging, the limestones record alternations of relatively high-and relatively low-energy settings, typical of lagoon and near-reef environments. Greater abundances of coral were noted at Site 966, relative to Site 965, including encrusting poritids, which suggest that, of the two sites, the more southerly Site 966 was located closer to coral reefs. Similar Miocene shallow-water and reef-related carbonates are known in other 


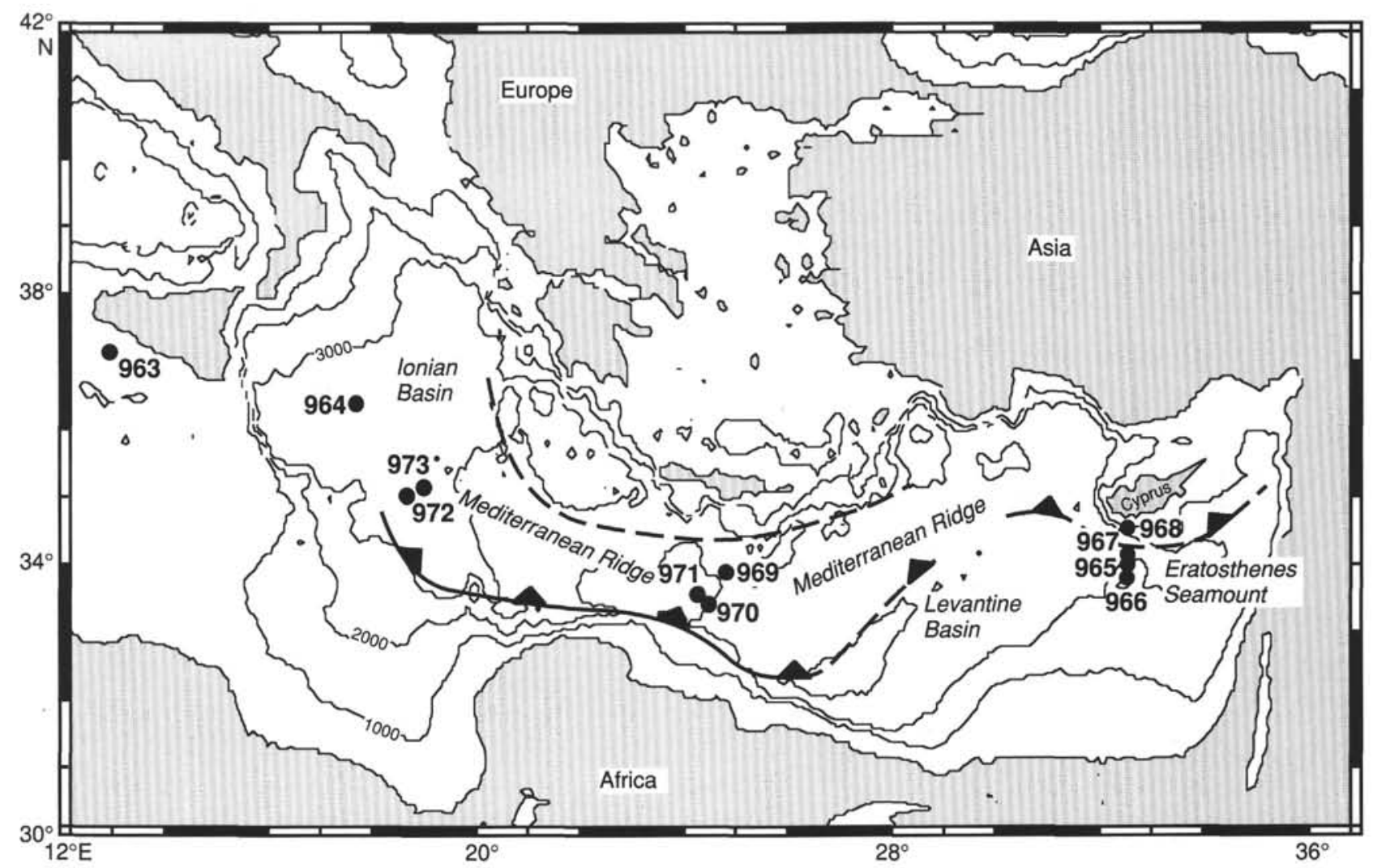

Figure 1. Outline map of the Mediterranean region showing the main tectonic features and the location of the sites drilled during Leg 160.

Figure 2. Summary of the sequences recovered from the Eratosthenes Seamount during Leg 160 (see text for explanation).

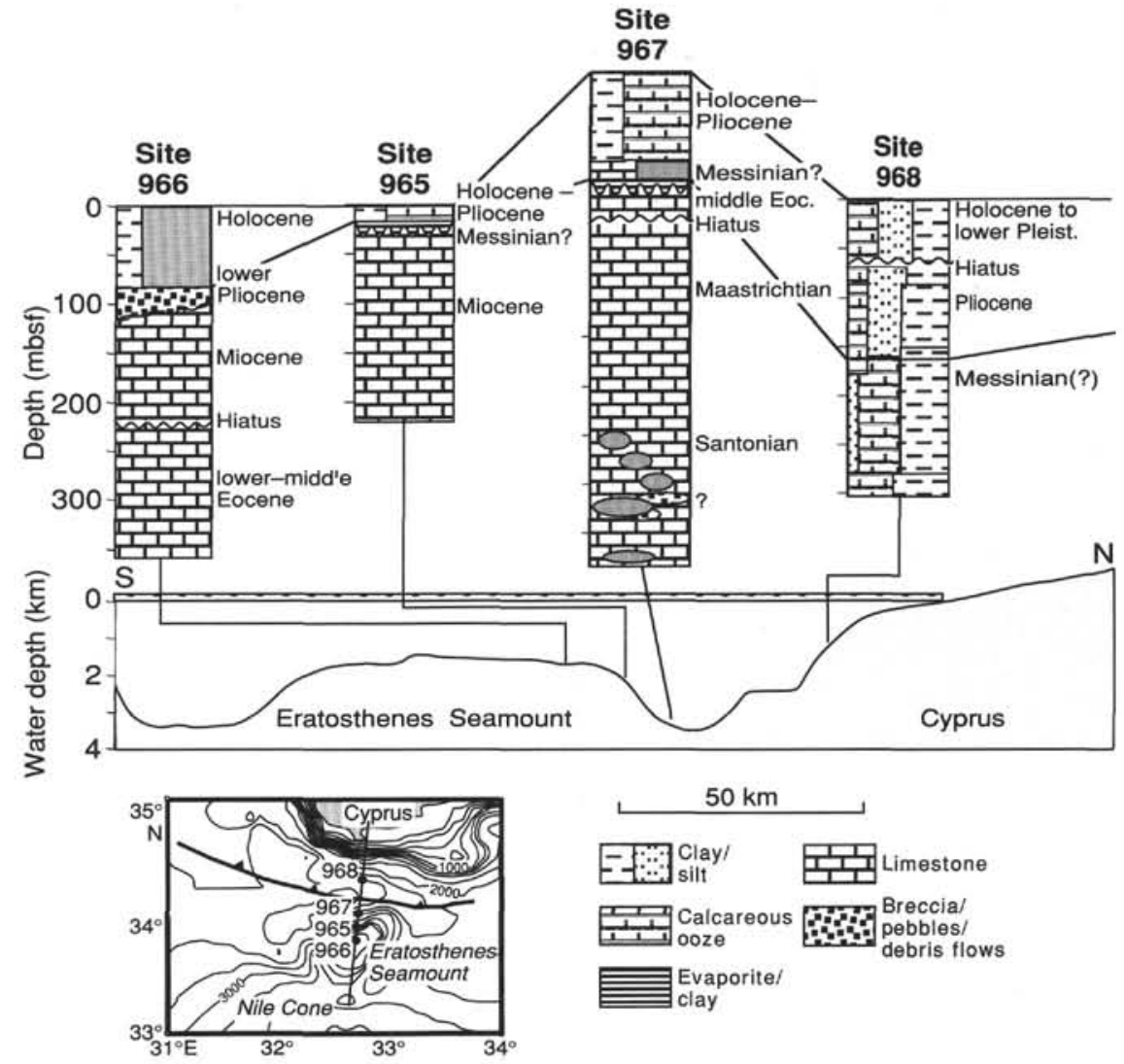



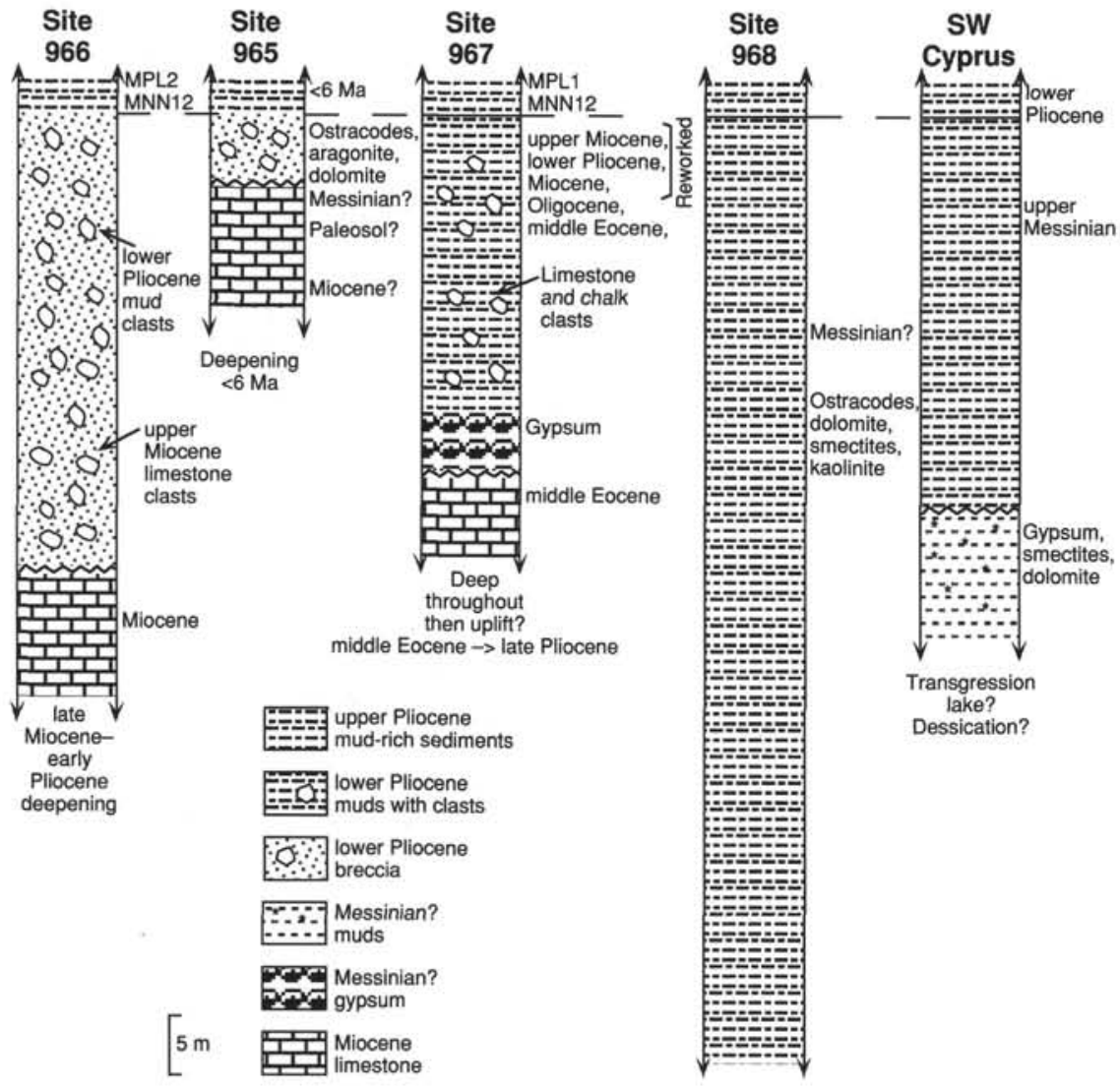

Figure 3. Summary logs of lower Pliocene sequences recovered during Leg 160; these document sedimentation associated with the breakup and collapse of the Eratosthenes Seamount (see text for explanation). areas of the Eastern Mediterranean including Israel, southern Turkey, and Cyprus (e.g., Follows, 1990; Follows and Robertson, 1990). In Cyprus, coralline limestones of both early Miocene and late Miocene age are developed as relatively small (i.e., hundreds of meters) patch reefs and fringing reefs. The lower Miocene reefs formed in a locally stable tectonic setting as small, low-relief patches surrounded by mainly fine-grained carbonates that are typically rich in benthic foraminifers, whereas the upper Miocene (Tortonian) reefs were controlled by active extensional faulting around the western and northern flanks of the Troodos ophiolite.

At the northernmost of the three Eratosthenes sites (Site 967) the Miocene is absent and the Upper Cretaceous-middle Eocene pelagic carbonates are directly overlain by fine-grained, deep-water sediments of early Pliocene age. Are the Miocene shallow-water carbonates similar to those at the more southerly sites? One clue is the presence, at the base of the lower Pliocene section, of reworked microfossils of middle Eocene, Oligocene, and Miocene-early Pliocene age. There is, therefore, some record of pelagic sedimentation during this time period at, or in the vicinity of, Site 967.

\section{MESSINIAN}

During the Messinian, the Mediterranean experienced its wellknown salinity crisis, as confirmed during Legs 13 and 42 of the Deep Sea Drilling Project (Hsü et al., 1973; Hsü, Montadert, et al., 1978). Layers of evaporite, up to several kilometers thick, are inferred to exist beneath the deep Mediterranean basin, based on recognition of a pronounced " $M$ " reflector on seismic profiles (Ryan et al., 1971; Ross and Uchupi, 1977; Woodside, 1977). The "M" reflector to the south and southwest of the Eratosthenes Seamount can be observed to pinch out upslope on the flanks of the Eratosthenes Sea- mount (Limonov et al., 1994). It was, therefore, inferred that the seamount was well above the level of the surrounding Mediterranean deep basin during the Messinian. A prominent reflector, thought to be an erosion surface, was noted at the base of the inferred Pliocene sequence. Drilling during Leg 160 confirmed that no thick evaporites are present on the Eratosthenes Seamount (Site 966) or on its northern flank (Sites 965 and 967; Fig. 3). The Messinian is thin, or absent, on the seamount. However, at Site 965 , several meters of red clays were recovered at the boundary between overlying sediments that contain early Pliocene age nannofossils and underlying shallow-water limestones. These clays contain ostracodes of possibly Messinian to early Pliocene age, together with dolomite, aragonite, and swelling clays. Also, at Site 967, near the base of an interval of muddy sediments that contains only reworked microfossils, a several-meterthick interval (not recovered) was identified on geophysical borehole $\log$ records as gypsum. Corroboration comes from inorganic geochemical evidence of greatly increased levels of soluble sulfate at this level and from geochemical borehole logging. We therefore conclude that, during the Messinian, the Eratosthenes Seamount existed as a topographically raised area that was marked by erosion and/or the local accumulation of gypsum and ferruginous muds, possibly in small marginal lagoons and/or lakes.

Regional plate tectonic reconstructions indicate that, by the Miocene, a plate boundary was in existence between the Eratosthenes Seamount and Cyprus to the north (Dewey and Şengör, 1979; Dercourt et al., 1993). For the interval from the Miocene to the Holocene it can be hypothesized that the Eratosthenes Seamount was located on the downgoing plate, while Cyprus was located on the overriding plate. If this is correct, the sedimentary and tectonic history of the $\mathrm{Cy}$ prus margin would be quite different from that of the Eratosthenes Seamount. Drilling at Site 968, near the foot of the slope of the Cyprus margin, reveals such contrasts. Beneath the Pliocene-Pleis- 
tocene succession, more than $200 \mathrm{~m}$ of argillaceous sediments, interbedded with calcareous turbidites, was recovered. The microfossils there are entirely reworked, but include abundant brackish-water ostracodes and the benthic foraminifer Ammonia tepida. Other clues as to the depositional setting include the presence of abundant clays (e.g., smectites) and kaolinite, together with scattered dolomite and local halite crystals. Several thin layers of detrital selenitic gypsum sands were also recovered, together with thin layers $(5 \mathrm{~cm})$ of finegrained alabastrine gypsum within clay. This could reflect accumulation in a nonmarine setting, possibly a large lake, or, alternatively, redeposition of gypsum from southern Cyprus and offshore areas.

As to the source of the abundant turbidites at Site 968, there is little doubt, because their constituents include numerous small lithoclasts of pelagic chalk and basalt and minerals that were clearly derived from the Troodos ophiolite and its sedimentary cover in southern Cyprus (e.g., the Miocene Pakhna Formation; Robertson et al., 1991). Gypsum is found in small tectonically controlled basins in southern Cyprus; in several cases the depocenters are now located offshore, providing possible source areas for the detrital gypsum found at Site 968 (Orszag-Sperber and Elion, 1989; Robertson et al., 1991). The existence of Messinian lakes was inferred in the Tyrrhenian Sea (Kastens, Mascle, et al., 1990). In general, lacustrine conditions are known to have prevailed widely in the late Messinian, especially in the circum-Black Sea region (Steininger and Rögl, 1984).

At Site 968, on the lower Cyprus slope, the composition of the pore waters clearly indicates the presence of halite at depth. Such halite may stratigraphically underlie the inferred lacustrine deposits; if so, the lacustrine sediments would be of late Messinian age (i.e., "Lago Mare" facies). On the other hand, evaporites might also have been underthrust as a result of northward subduction. In summary, strata of inferred Messinian age on the Eratosthenes Seamount (Sites 965, 967, and 968) are thin or absent, whereas, at Site 968, a thick (i.e., hundreds of meters) section of probable late Miocene age lacustrine facies (i.e., the "Lago-Mare") is present.

\section{EARLY PLIOCENE}

All of the sites drilled document the refilling of the Mediterranean at the end of the Messinian desiccation crisis (Hsü, Montadert, et al., 1978). However, conditions varied at individual sites. At Site 965, on the upper slope of the seamount, a thin $(6 \mathrm{~m})$ inferred Messinian interval contains rare, poorly preserved nannofossils between 3.5 and 6 m.y. in age (i.e., they indicate late Miocene-early Pliocene ages). There are also possible paleosols within an interval of reddish and brownish sticky clay. In this vicinity, the base of the Pliocene is marked by a sharply defined, flat, seismic reflector, consistent with the presence of a sharp lithology contrast between Miocene limestone below and the weakly consolidated Pliocene fine-grained sediments above. A similar well-defined reflector is present at Site 967 to the north, where the interval between the lower Pliocene and middle Eocene includes scattered clasts of chalk and limestone and, as noted earlier, reworked foraminifers of Eocene and Oligocene age, in addition to long-ranging forms that span late Miocene and/or early Pliocene time. A source of both well-lithified and unlithified carbonates must have existed in the vicinity of Site 967.

The most informative sedimentary facies within the transitional unit was recovered at the southernmost of the Eratosthenes sites, Site 966. In this area, the seismic character of the unconformity at the base of the Pliocene succession is much less distinct than in adjacent parts of the seamount. Here, some $65 \mathrm{~m}$ of interbedded nannofossil muds and debris flows was recovered (Fig. 3). Despite the presence of drilling artifacts (i.e., drilling "biscuits" and piston "suck-in" effects), a primary stratigraphy can be discerned. Particularly convincing is the presence of a well-preserved, fine primary lamination and zones of coarse clastic sediment that are sufficiently well-cemented to dis- count their formation as a result of drilling disturbance. The sequences were geophysically logged in four adjacent holes, allowing detailed comparisons. In general, an initial clast-rich interval passes into a more clay-rich interval, with several intercalations that are rich in detrital clasts. Many of the clasts are composed of shallow-water limestones that are similar to the underlying unit; one such clast contains microfossils of Miocene age, and a number of the mud clarts include nannofossils of early Pliocene age. Most of the clasts are angular to subangular; the texture is matrix supported throughout. Several of the limestone clasts exhibit a tectonically fractured fabric. A narrow interval near the top of the section in Hole $966 \mathrm{E}$ contains small $(\sim 3 \mathrm{~cm})$, well-rounded clasts of gray micritic limestone. A few clasts are rounded and show evidence of pitting and abrasion. The available evidence indicates that the matrix-supported breccia units at Site 966 formed by erosion of a source area that included Miocene limestones. Accumulation was, however, entirely marine and relatively deep, judging from the ubiquitous planktonic biota. Erosion of the limestones might have been subaerial, subaqueous, or both, but there is little evidence of clast rounding via sedimentary transport. In an exceptional case, the presence of well-rounded clasts indicates at least some derivation from a high-energy shallow-marine, or beach, setting. The presence of a tectonic fabric within several clasts could suggest derivation from a faulted rock (e.g., an erosional fault scarp). The presence of clasts of nannofossil mud further indicates that deepmarine sediments were reworked, probably in response to continued local tectonic instability.

In summary, it is inferred that the dominantly matrix-supported breccia unit at Site 966 formed mainly by mass-flow processes in a highly tectonically unstable deep-sea setting. A similar, but less pronounced, history of tectonic instability, with the erosion of limestone and redeposition of clasts in a deep-marine setting, is documented at Site 965 . It is clear that such tectonic instability and faulting were active at, and probably prior to, $4.5 \mathrm{Ma}$ (i.e., early Pliocene).

An entirely different Miocene/Pliocene transition is documented at the base of the Cyprus slope at Site 968. Assuming that the lower clay-rich unit is of Messinian age (with only reworked microfossils), the upward transition to the early Pliocene is marked by an incoming of age-diagnostic nannofossils and planktonic foraminifers. Input of calcareous turbidites, derived from Cyprus, continued with no obvious break during the inferred Messinian/early Pliocene transition. Site 968 can be interpreted as already located well below eustatic sea level in the Messinian, so that deep-marine sedimentation was recorded in the early Pliocene following marine transgression.

Onshore in southern Cyprus, uplift to near sea level had already taken place by the early Miocene, although pelagic carbonate deposition persisted in some local basins. During the Messinian, gypsum accumulated in small basins, notably the Polemi basin in western $\mathrm{Cy}$ prus and the Maroni basin of southern Cyprus (Robertson et al., 1991).

\section{PLIOCENE-PLEISTOCENE}

At each of the four sites drilled, the Pliocene-Pleistocene sequence records deep-marine accumulation. The Eratosthenes Seamount and its flanks were then at water depths ranging from 700 to $2900 \mathrm{~m}$. Much of this subsidence took place rapidly, as indicated by microfossils of early Pliocene age that were already of deep-marine type. Further deepening took place after the late Pliocene, at least at Site 967 , as benthic foraminifers there indicate an upward deepening.

The Eratosthenes Seamount experienced tectonic disturbance during late Pliocene-Pleistocene time. A hiatus of a maximum of 0.5 m.y. exists within the late Pliocene-early Pleistocene time interval at Sites 965 and 967 on the Eratosthenes slope. At Site 966, extremely slow sedimentation rates ( $1-2 \mathrm{~m} / \mathrm{m}$.y.) suggest that a depositional hiatus may be present in the early Pleistocene, although no paleontological zones are missing. The hiatuses could reflect deformation of 
the Eratosthenes plateau area, as evidenced by low-angle discordances and folding that are observable on high-resolution deep-tow seismic records (Limonov et al., 1994). The probable cause of this deformation is block faulting of the underlying pre-Pliocene-Pleistocene rocks. It is still unclear whether a similar hiatus is present at Site 968 on the Cyprus lower slope because the foraminifers and nannofossils give different results.

Interpretations of the seismic data indicate that a small ridge at the base of the lower slope of the Eratosthenes Seamount at Site 967 is underlain by a northward-dipping fault zone (i.e., a reverse fault or thrust). It was previously hypothesized that this ridge is in the process of being tectonically detached from the Eratosthenes Seamount ( $\mathrm{Li}$ monov et al., 1994; Robertson et al., 1994, 1995). An objective of drilling at Site 967 was to test if there is any evidence of such a zone of reverse faulting. The faulting must be relatively recent, because the Pliocene-Pleistocene sediments that form the ridge are evidently deformed on seismic profiles. Also, the ridge has a small sedimentary basin ponded against it to the south. This basin is well imaged on deep-tow high-resolution seismic profiles (Limonov et al., 1994). The same high-resolution records show that the small basin is deformed by numerous upright folds, with estimated wavelengths of only a few meters. The folds are interpreted to result from shortening of the sedimentary basin fill, which is associated with movement on the upthrust ridge to the south. Reverse faults are also imaged directly to the south, on the lower slope of the Eratosthenes Seamount. The results from drilling at Site 967 indicate that the majority of faults observed in the cores of Eocene and Upper Cretaceous limestone have normal offsets. The sequence ends with a tectonic breccia composed of limestone. The Formation MicroScanner log data suggest that numerous zones of deformation and brecciation are present. It is, therefore, inferred that Site 967 has experienced a complex history of both extensional and compressional deformation.

The matrix-supported breccias of early Pliocene age on the Eratosthenes crestal plateau area could be fault generated. Such faults would have remained active, at least for some time in the PliocenePleistocene. This view is supported by the existence of isolated clasts of shallow-water limestone within nannofossil muds and oozes not far beneath the seafloor at Site 966. Furthermore, there is strong evidence that Site 965 , today located on the steep fault-bounded upper slopes of the Eratosthenes Seamount, already formed part of a sloping seafloor area during much, or all, of Pliocene-Pleistocene time. The nannofossil muds and oozes there show extensive evidence of slumping and reworking, as debris flows.

Seismic evidence indicates that the plateau area of the Eratosthenes Seamount is tectonically active. A set of nearly east-westoriented faults, which occur in an area up to several hundred meters in width, cuts the uppermost seismic reflectors; some of these faults expose lithified fault-wall rocks on the seafloor (Limonov et al., 1994). Evidence of Pleistocene to Holocene instability is also suggested by the common existence of fine-grained mud turbidites in the upper part of the sequence at Site 966 . Such turbidites most likely resulted from resuspension of sediment from within the plateau area. By contrast, thin, steel gray mud turbidites in the uppermost part of the succession at the base of the Eratosthenes Seamount slope (Site 967) were deposited from dilute gravity flows that contain mica, biotite, and other minerals that suggest derivation from the Nile River.

\section{TESTING MODELS OF INCIPIENT CONTINENTAL COLLISION}

Below, we use information gained by drilling (Fig. 4) to test alternate tectonic models of the Eratosthenes Seamount as a crustal fragment in the process of collision with Cyprus, in a setting along the active boundary between the African and Eurasian plates.

The pre-Late Cretaceous tectonic setting of the Eratosthenes Seamount remains uncertain (Fig. 5A). The gravity and magnetic data have been interpreted to suggest that igneous rocks (i.e., intrusions or extrusions) may be present at depth beneath the seamount, and these are possibly located within a continent/ocean boundary transition zone (Woodside, 1977, 1991). Alternatives are (1) that the seamount has remained deeply submerged as part of the passive margin of the North African plate and was first uplifted to form a raised feature in the Miocene or (2) that it existed from the time of continental breakup as a promontory or crustal block adjacent to the passive margin. The fact that the recovered Upper Cretaceous and Eocene deep-water successions lack evidence of turbidites suggests that Eratosthenes Seamount was perhaps already elevated above the surrounding seafloor, as a submerged feature that was then uplifted in the Miocene.

The picture becomes clearer from the late Miocene onward. Sitesurvey work performed prior to Leg 160 formed the basis for testing a tectonic model involving collision of the Eratosthenes Seamount with the Cyprus active margin. Key features of the model are that the northern margin of the seamount is being actively downfaulted from a depth of approximately 800 to $2000 \mathrm{~m}$ over a distance of about 50 $\mathrm{km}$ and is in the process of being thrust beneath Cyprus to the north (Limonov et al., 1994; Robertson et al., 1994, 1995). The plateau area is also undergoing active extensional faulting possibly related to crustal loading. The transition from a zone of downfaulting to the south to a zone of shortening in the north was taken to be in the vicinity of the small raised ridge near the foot of the northern slope of the Eratosthenes Seamount (at Site 967; Fig. 4D). The ridge is assumed to be a fragment of upfaulted Eratosthenes Seamount rocks that was detached by reverse faulting and thrusting. In contrast, the Cyprus margin to the north exhibits a different tectonic-sedimentary history that would be expected to record contemporaneous uplift, in contrast to the subsidence of the Eratosthenes Seamount to the south.

An effective test of the above model requires consideration of the following aspects.

\section{Eratosthenes Seamount Formed Part of the Passive Margin of the African Plate during its Precollisional History}

Each of the three sites drilled across the Eratosthenes Seamount (Sites 965, 966, and 967) represent part of a single tectono-stratigraphic unit. During the late Mesozoic, the Eratosthenes Seamount formed part of a carbonate platform, as is widely exposed around the Eastern Mediterranean (e.g., especially in the Levant; Dercourt et al., 1993; Fig. 5A). The Late Cretaceous deep-water pelagic carbonate record of the Eratosthenes Seamount lacks any evidence of the significant tectonic events that were in progress within the Tethys to the north, including deformation and emplacement of Upper Cretaceous ophiolites (Fig. 5B). The sedimentary record of the Eratosthenes Seamount is consistent with its evolution as part of the passive margin of the African plate for at least the last 85 m.y.

\section{Whether the Eratosthenes Seamount Was Deformed Prior to Continental Collision}

Uplift from a bathyal environment, in which pelagic carbonates were deposited in the middle Eocene, to shallow-water environments where reefal limestones of Miocene age accumulated (greater than several hundred meters) probably more than can be accounted for either as a result of eustatic sea-level change or by the effects of flexural faulting related to incipient continental collision. The question arises as to whether uplift of the Eratosthenes Seamount in the Miocene was the result of initial collision with the Cyprus active margin to the north or if the uplift predated such collision.

Evidence from southern Cyprus (Robertson et al., 1991) and Crete (Meulenkamp et al., 1994) suggests that northward subduction along the present plate boundary between the African and Eurasian plates in the Eastern Mediterranean region may have begun at about the base of the Miocene. In eastern Turkey, collision of the Arabian subplate with southern Turkey had finally closed the southernmost strand of the Mesozoic Tethys Ocean by late Oligocene to early Mi- 

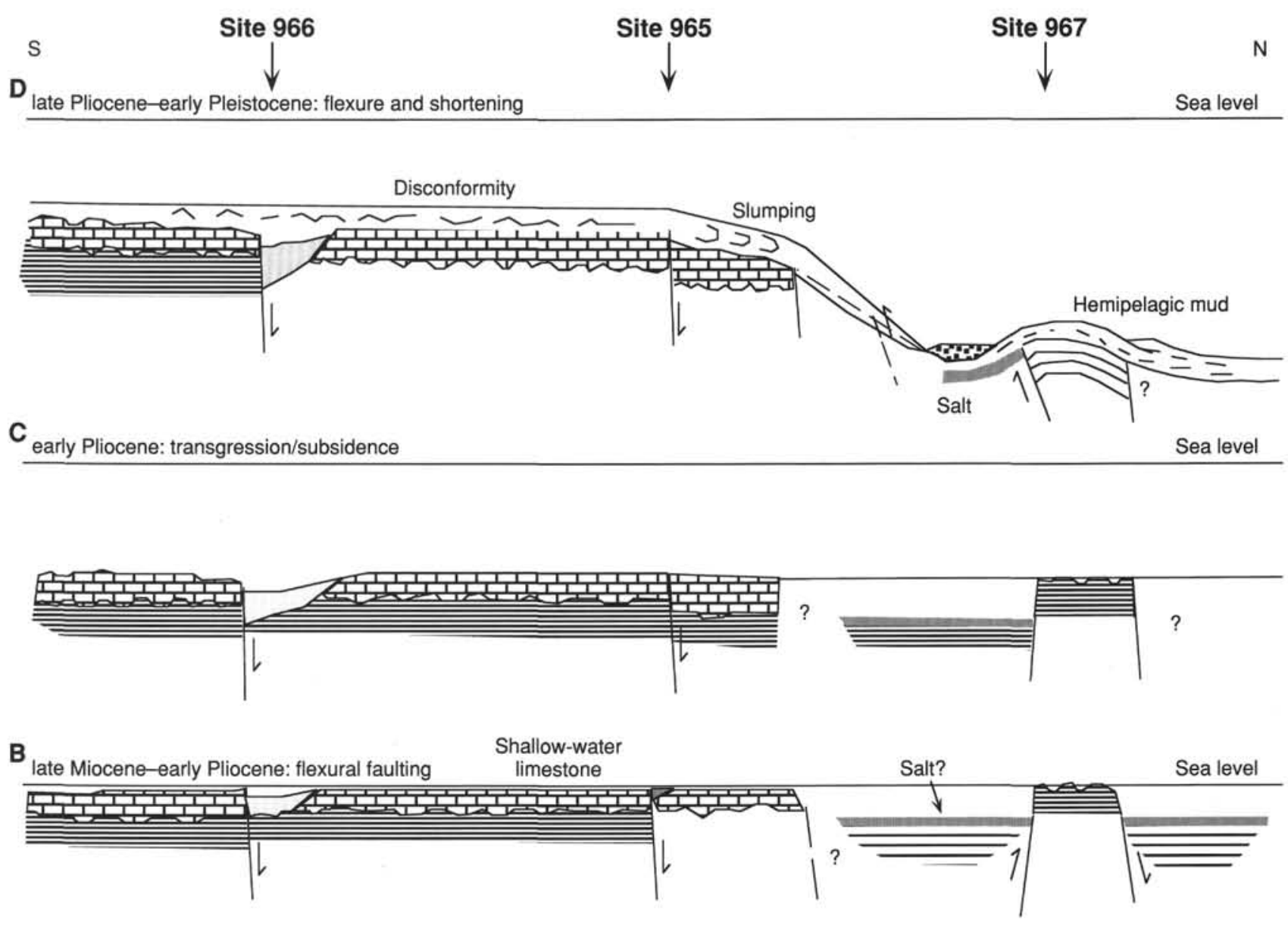

A

Late Cretaceous-early Tertiary: bathyal

Sea level

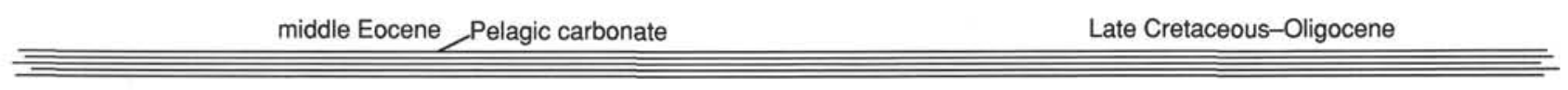

Figure 4. Inferred tectonic history of the northern margin of the Eratosthenes Seamount (see text for explanation).

ocene time (Şengör et al., 1985), leaving the eastern Mediterranean Sea as the only large area of remnant Mesozoic oceanic crust where subduction could continue. Uplift of the Eratosthenes Seamount after the middle Eocene could thus be interpreted as a regional crustal shortening event, perhaps related to the onset of northward subduction in the Eastern Mediterranean; if so, this would have predated the initial collision of the Eratosthenes Seamount with the Cyprus margin to the north (Fig. 5C). In should be noted, however, that by the Miocene, little effective separation remained (i.e., several hundred kilometers) between the African and Eurasian plates in the Eastern Mediterranean and, thus, it can be safely assumed that the Miocene uplift of Eratosthenes Seamount was somehow subduction related. It is also possible that collision may have begun by early Miocene time, but it did not result in strong deformation as would be recorded in the sedimentary succession.

\section{Nature and Timing of Faulting}

Evidence of important, predominantly extensional, faulting was found in both the middle Eocene sequence at Site 966 and the Upper Cretaceous and middle Eocene sequence at Site 967. Of the two sites, such faulting is more pervasive at Site 967. The main evidence of this faulting is the presence of numerous small normal faults within cores of well-cemented limestone. Little can be said about the timing of the faulting, other than that it took place after lithification. Early Pliocene age matrix-supported breccias (e.g., at Site 966) are more age diagnostic and were possibly shed from a fault-controlled topography into a deepening sea that was undergoing rapid sedimentation (of up to 80 $\mathrm{m} / \mathrm{m} . \mathrm{y}$.). It is probable that faulting and subsidence of the Eratosthenes Seamount took place mainly during the early Pliocene (i.e., at about $5 \mathrm{Ma}$ ), based on the age ranges determined from clasts within the breccia unit. However, subsidence may well have begun earlier, during the Messinian or even before.

\section{Subsidence as the Result of Tectonic Loading}

An exponential increase in the subsidence rate with time would be anticipated. Similar subsidence was determined for a number of foreland areas affected by thrust emplacement (e.g., Rocky Mountains, Appalachians, Himalayas; Beaumont, 1981). A similar subsidence rate would therefore appear likely in the Eratosthenes area. At present, the paleontological evidence is adequate only to infer that subsidence of the Eratosthenes Seamount was extremely rapid at about the Miocene/Pliocene boundary. It is likely that such faulting 


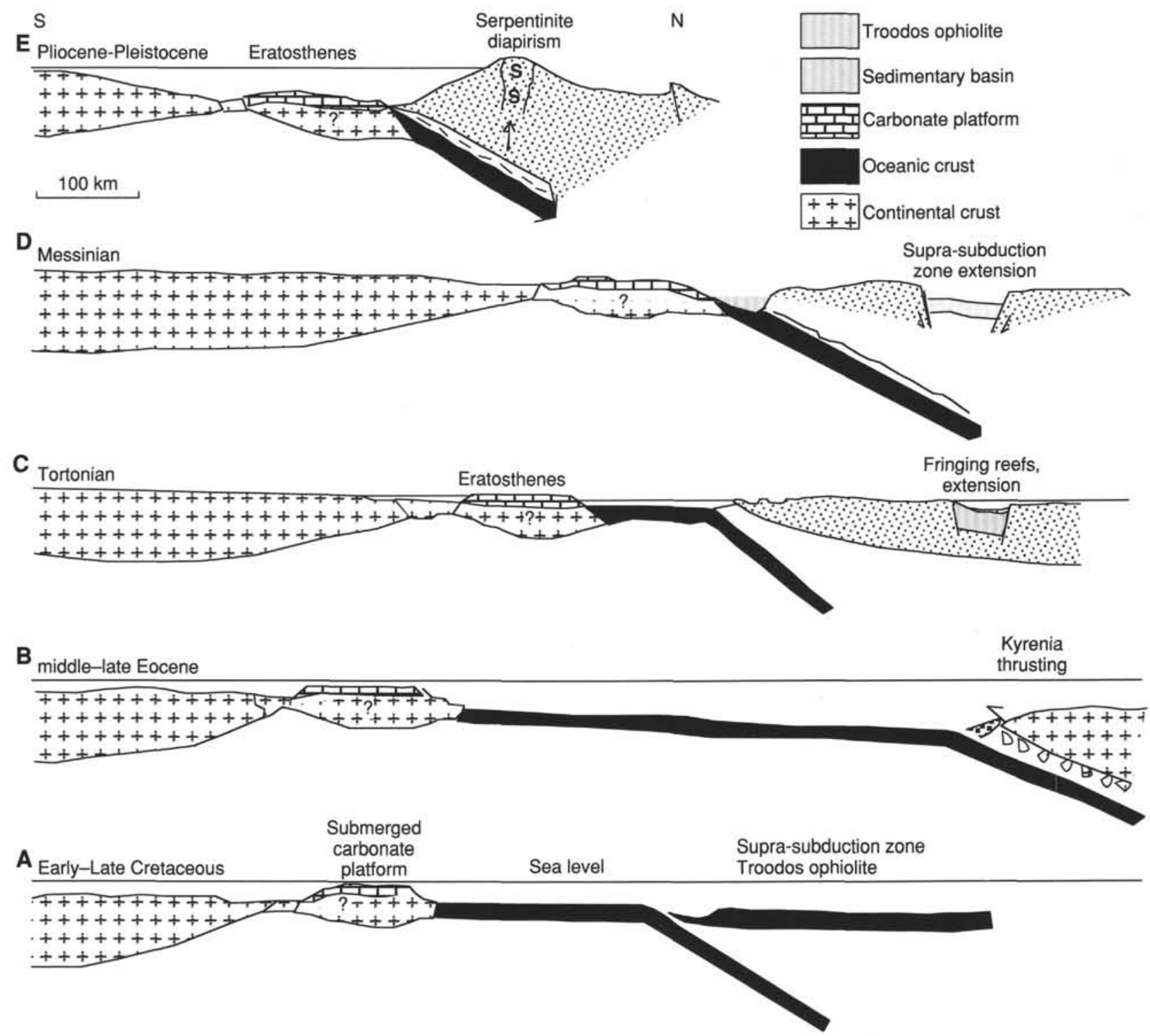

Figure 5. Plate tectonic model for the evolution of the Eratosthenes Seamount in relation to Cyprus (see text for explanation).

was initiated when the effects of thrust loading exceeded the flexural rigidity of the crust. The incoming Eratosthenes slab formed part of old (i.e., Mesozoic or older) crust that would, on theoretical grounds, be expected to have acted in a relatively rigid manner (Stockmall et al., 1986). On the other hand, field studies in a number of areas, including the Paleozoic Appalachians (Whiting and Thomas, 1994) and the Mesozoic Tethyan belt (Flecker et al., 1995) have shown that inherited fault structures exert a major control on the localization and extent of flexurally induced faulting. It is thus inferred that the arrival of the Eratosthenes Seamount at the Cyprus active margin caused flexural faulting and collapse.

\section{Link with the Uplift of Cyprus}

Following initial collision in the late Miocene to early Pliocene, the Eratosthenes Seamount continued to be tectonically active, associated with thrusting beneath Cyprus during the Pliocene-Pleistocene (Fig. 5D, E). However, the inferred time of tectonic collapse of the Eratosthenes Seamount is not synchronous with the main period of uplift of southern Cyprus, which took place after the late Pliocene (Robertson, 1990; McCallum and Robertson, 1990; Poole and Rob- ertson, 1992; Fig. 6). The uplift of Cyprus was not simply driven by collisional processes alone. The Troodos ophiolite is cored by serpentinite that has been modeled, based on gravity data, as a deeprooted cylindrical structure (Gass and Masson-Smith, 1963). Moores and Vine (1971) attributed the entire uplift of Cyprus to the effects of upward protrusion of serpentinite. In their model, Layer 3 rocks of the ophiolite, which consist mainly of depleted mantle harzburgites, were hydrated and rose upward diapirically, carrying the surrounding crust of Cyprus with them. More recently, it has become clear that the uplifted region is much greater than merely the Troodos ophiolite alone and includes the Kyrenia Range of northern Cyprus and its eastward prolongation through the Misis Mountains of southern Turkey. It is, thus, necessary to infer that the uplift of Cyprus took place as a result of both regional collision and serpentinite diapirism.

\section{CONCLUSIONS}

A transect of four drill sites across the Eratosthenes Seamount to the Cyprus margin has established the late Mesozoic to present-day sedimentary and tectonic evolution of the long-enigmatic Era- 


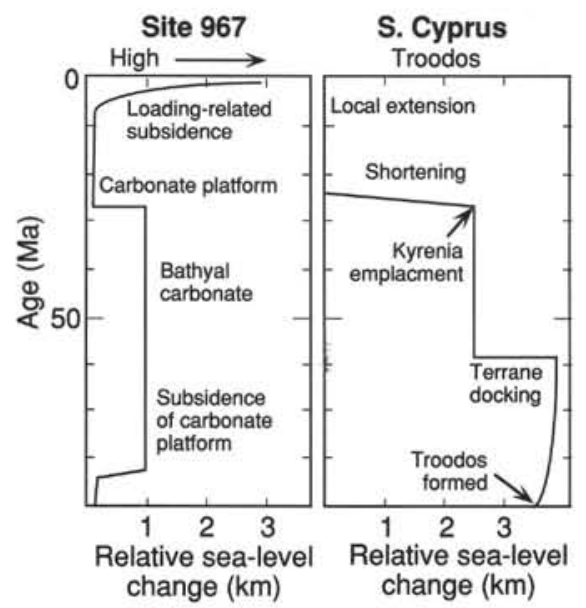

Figure 6. Curve of relative sea-level change of the Eratosthenes Seamount compared with that for Cyprus (see text for explanation). These trends emphasize the tectonic-sedimentary history of the Eratosthenes Seamount and southern Cyprus. On the other hand, the history of the seamount is more similar to that of the African plate, including the Levant.

tosthenes Seamount in the Eastern Mediterranean. A 50-m.y. history as part of the passive margin of the North African plate was followed by uplift and deposition of shallow-water platform carbonates in the Miocene, which was followed by emergence during the Messinian salinity crisis (Fig. 6). Mass-flow deposition and breakup, associated with rapid subsidence, took place in the late Miocene to early Pliocene, and are interpreted to represent the result of collision with the Cyprus active margin to the north. Initial impingement took place at about $5 \mathrm{Ma}$ (or earlier), followed by intense uplift of Cyprus about 3 m.y. later.

\section{REFERENCES}

Beaumont, C., 1981. Foreland basins. Geophys. J. R. Astron. Soc., 65:291329.

Cita, M.B., and Camerlenghi, A., 1990. The Mediterranean Ridge as an accretionary prism in collision context. Mem. Soc. Geol. Ital., 45:463480.

Dercourt, J., Ricou, L.F., and Vrielynck, B. (Eds.), 1993. Atlas of Tethys Palaeoenvironmental Maps: Paris (Gauthier-Villars).

Dewey, J.F., and Şengör, A.M.C., 1979. Aegean and surrounding areas: complex multi-plate and continuum tectonics in a convergent zone. Geol. Soc. Am. Bull., 90:84-92.

Flecker, R., Robertson, A.H.F., Poisson, A., and Muller, C., 1995. Facies and tectonic significance of two contrasting Miocene basins in south coastal Turkey. Terra Nova, 7:221-232.

Follows, E.J., 1990. Sedimentology and tectonic setting of Miocene reef and related sediments in Cyprus [Ph.D. thesis]. Univ. Edinburgh, Scotland.

Follows, E.J., and Robertson, A.H.F., 1990. Sedimentology and structural setting of Miocene reefal limestones in Cyprus. In Malpas, J., Moores, E.M., Panayiotou, A., and Xenophontos, C. (Eds)., Ophiolites: Oceanic Crustal Analogues: Nicosia, Cyprus (Geol. Surv. Dep., Minist. Agric. Nat. Resour.), 207-216.

Gass, I.G., and Masson-Smith, D., 1963. The geology and gravity anomalies of the Troodos Massif, Cyprus. Phil. Trans. R. Soc. London A, 255:417467.

Hsü, K.J., Montadert, L., et al., 1978. Init. Repts. DSDP, 42 (Pt. 1): Washington (U.S. Govt. Printing Office).

Hsü, K.J., Cita, M.B., and Ryan, W.B.F., 1973. The origin of the Mediterranean evaporites. In Ryan, W.B.F., Hsü, K.J., et al., Init. Repts. DSDP, 13 (Pt. 2): Washington (U.S. Govt. Printing Office), 1203-1231.
Kastens, K.A., Mascle, J., et al., 1990. Proc. ODP, Sci. Results, 107: College Station, TX (Ocean Drilling Program).

Kempler, D., 1993. Tectonic patterns in the Eastern Mediterranean [Ph.D. thesis]. Hebrew Univ., Jerusalem.

Limonov, A.F., Woodside, J.M., and Ivanov, M.K. (Eds.), 1994. Mud Volcanism in the Mediterranean and Black Seas and Shallow Structure of the Eratosthenes Seamount. UNESCO Rep. Mar. Sci., 64.

McCallum, J.E., and Robertson, A.H.F., 1990. Pulsed uplift of the Troodos Massif: evidence from the Plio-Pleistocene Mesaoria Basin. In Malpas, J., Moores, E.M., Panayiotou, A., and Xenophontos, C. (Eds.), Ophiolites: Oceanic Crustal Analogues. Proc. Symp. "Troodos 1987": Nicosia, Cyprus (Geol. Surv. Dep., Minist. Agric. Nat. Resour.), 217-229.

Moores, E.M., and Vine, F.J., 1971. The Troodos Massif, Cyprus and other ophiolites as oceanic crust: evaluation and implications. Philos. Trans. $R$. Soc. London A, 268:443-466.

Meulenkamp, J.E., Wortel, M.J.R., van Wamel, W.A., Spakman, W., and Hoogerduijn Strating, E., 1988. On the Hellenic subduction zone and the geodynamic evolution of Crete since the late middle Miocene. Tectonophysics, 146:203-215.

Orszag-Sperber, F., Rouchy, J.M., and Elion, P., 1989 The sedimentary expression of regional tectonic events during the Miocene-Pliocene transition in the southern Cyprus basins. Geol. Mag., 126:291-299.

Poole, A.J., and Robertson, A.H.F., 1992. Quaternary uplift and sea-level change at an active plate boundary, Cyprus. J. Geol. Soc. London, 148:909-921.

Robertson, A.H.F., 1990. Tectonic evolution of Cyprus. In Malpas, J., Moores, E.M., Panayiotou, A., and Xenophontos, C. (Eds.), Ophiolites: Oceanic Crustal Analogues. Proc. Symp. "Troodos 1987": Nicosia, Cyprus (Geol. Surv. Dep., Minist. Agric. Nat. Resour.), 235-250.

Robertson, A.H.F., Eaton, S., Follows, E.J., and McCallum, J.E., 1991. The role of local tectonics versus global sea-level change in the Neogene evolution of the Cyprus active margin. Spec. Publ. Int. Assoc. Sediment., 12:331-369.

Robertson, A.H.F., Kidd, R.B., Ivanov, M.K., Limonov, A.F., Woodside, J.M., Galindo-Zaldivar, J., and Nieto, L., 1994. Probing continental collision in the Mediterranean Sea. Eos, 75:233, 239.

Robertson, A.H.F., Kidd, R.B., Ivanov, M.K., Limonov, A.F., Woodside, J.M., Galindo-Zaldivar, J., Nieto, L., and the Scientific Party of the 1993 TTR-3 Cruise, 1995. Eratosthenes Seamount, easternmost Mediterranean: evidence of active collapse and underthrusting beneath the Cyprus active Margin. Terra Nova, 7:254-264.

Ross, D.A., and Uchupi, E., 1977. Structure and sedimentary history of southeastern Mediterranean Sea-Nile Cone. AAPG Bull., 61:872-902.

Ryan, W.B.F., Stanley, D.J., Hersey, J.B., Fahlquist, J.B., and Allen, T.D., 1971. The tectonics and geology of the Mediterranean Sea. In Maxwell, A. (Ed.), The Sea (Vol. 4): New York (Wiley), 387-492.

Şengör, A.M.C., Görür, N. and Sarioğlü, F., 1985. Strike-slip faulting and related basin formation in zones of tectonic escape: Turkey as a case study. In Biddle, K.T., and Christie-Blick, N. (Eds.), Strike-slip Deformation, Basin Formation and Sedimentation. Soc. Econ. Paleont. Mineral., Spec. Publ., 37:227-264.

Steininger, F.F., and Rögl, F., 1984. Paleogeography and palinspastic reconstruction of the Neogene of the Mediterranean and Paratethys. In Dixon, J.E., and Robertson, A.H.F. (Eds.), The Geological Evolution of the Eastern Mediterranean. Geol. Soc. Spec. Publ. London, 17:659-668.

Stockmall, G.S., Beaumont, C., and Boutilier, R., 1986. Geodynamic models of convergent margin tectonics: transition from a rifted margin to overthrust belt and consequences for foreland-basin development. AAPG Bull., 70:181-190.

Whiting, B.M., and Thomas, W.A., 1994. Three-dimensional controls on subsidence of a foreland basin associated with a thrust-belt recess: Black Warrior basin, Alabama and Mississippi. Geology, 22:727-730.

Woodside, J.M., 1977. Tectonic elements and crust of the eastern Mediterranean Sea. Mar. Geophys. Res., 3:317-354.

, 1991. Disruption of the African Plate margin in the eastern Mediterranean. In Salem, M.J., Sbeta, A.M., Bakbak, M., and Rida, M. (Eds.), The Geology of Libya: Symp. Geol. Libya 3, 6:2319-2329.

\section{Ms 160IR-118}

